социально ответственный маркетинг, маркетинг взаимоотношений, в том числе маркетинг персонала) позволяет говорить лишь о начале научного поиска в данном проблемном поле.

$$
* * *
$$

1. Артеменкова, А.О. Роль холистического маркетинга как инструмента развития компаний сферы услуг // Сервис в России и за рубежом. 2011. № 4. С. 46-52.

2. Буреш О.В., Калиева О.М. Парадигма холистического маркетинга как результат эволюции концепций управления // Вестник Оренбургского государственного университета. 2014. №8 (169). С. 205-211.

3. Воронов А.А. Производительность труда как основа конкурентоспособности // Пищевая промышленность. 2002. № 7. С. 12-14.

4. Тамберг В., Бадьин А. 4P? 7C? 2Ц! Или каким должен быть маркетинг. URL: http://www.executive.ru/community/magazine/688953-viktor-tamberg-andrei-badin-4r-7s-2ts-ili-kakim-dolzhen-bytmarketing

5. Терещенко В.М. Маркетинг-терапия. СПб., Питер, 2004. С. 178.

6. Kotler Ph., Keller K.L., Ancarani F., Costabile M. Marketing management. NJ, Pearson. 2014.

\title{
Демьянченко Н.В. \\ Интегрированная компетенция как основа конкурентоспособной модели маркетинга персонала
}

Краснодарский филиал ФГБОУ ВО «Российский экономический университет им. Г.В. Плеханова» (Россия, Краснодар)

doi: $10.18411 / l j-28-02-2018-07$

idsp: 000001:lj-28-02-2018-07

\section{Аннотация}

Основой авторского подхода к разработке модели маркетинга персонала, ориентированной на воспроизводство и монетизацию человеческого капитала стала фиксация факта о необходимости формирования у персонала эффективного набора компетенций, обеспечивающих в той или иной степени самостоятельное ведение операционной деятельности вначале в составе базовой / материнской организации, а затем - за ее пределами.

Ключевые слова: маркетинг персонала, компетенция персонала, маркетинговая модель роста компетенции персонала

Авторская модель относится к аналоговому типу и раскрывает маркетинговый механизм мобилизации и продуктивного использования персонала организации:

- первоначально - в рамках ресурсного подхода, подразумевающего объектное значение персонала и соответствующие маркетинговые воздействия, направленные на развитие его профессиональной и организационной компетенции (при необходимости - также коррекция базовых уровней личной и командной компетенций, необходимых для организационного взаимодействия внутри структуры предприятия);

- следующий этап - масштабирование бизнес-модели материнской компании - подразумевает качественную трансформацию уровня взаимодействия организации с наиболее компетентными в профессиональном и организационном плане представителями персонала, способными при ресурсной и маркетинговой поддержке базового предприятия к переходу в ранг субъектов - маркетинговых партнеров материнской компании (в ранге дочерних или независимых бизнес-единиц или организаций). На этом этапе маркетингового взаимодействия стратегия материнской (базовой) организации перенаправляется на поиск маркетинговых и ресурсных конкурентных преимуществ, в то время как основная часть производственной функции 
реализуется бывшим персоналом в рамках новой организационной структуры самостоятельно;

- возможным к практической реализации как в логической последовательности после, так и параллельно этапу масштабирования бизнес-модели является этап мультиплицирования бизнес-модели материнской компании, в рамках которого уже дочерние компании становятся базой для дальнейшего горизонтального и/или вертикального развития, подразумевающего создание новых организационных структур в смежных / новых видах деятельности, повышение охвата цикла создания ценности в цепочке.

Отметим, что логика подобного сетевого развития оправданна именно на основе потенциала действующего персонала предприятия / организации, вовлеченного в ее деятельность, обладающего видением и способностью к самореализации в рамках маркетинговой концепции партнерских отношений, способного к самостоятельному масштабированию / мультиплицированию производственных функций и видов экономической деятельности.

Область применения данной модели тесно связана с формализацией стратегического маркетингового выбора организаций при определении перспективных направлений развития и выборе форматов реализации деятельности по их достижению. Необходимо подчеркнуть, что именно персонал организации наиболее подходит для масштабирования / мультиплицирования ее деятельности, поскольку работники обладают знанием сложившейся корпоративной культуры, владеют навыками взаимодействия с партнерскими структурами, осведомлены о реальных и перспективных конкурентных преимуществах и компетенциях базовой предпринимательской структуры. С другой стороны, переформатирование роли персонала как субъекта маркетинга взаимоотношений открывает качественно новые возможности для его вовлечения, по сути, открывает каждому заинтересованному и компетентному работнику реальный путь для создания и развития же собственного бизнеса.

Следует признать морально устаревшим подход, в рамках которого «человеческий капитал» личности, а если быть более точным - ее трудоспособность, рассматривалась как ресурс и объект долгосрочного использования в целях предпринимательской деятельности (в том числе с позиций присвоения создаваемой стоимости). В современном понимании термина, человеческий капитал персонала организации, по нашему мнению, состоит в его возможности участия не только в текущей / операционной деятельности, но и в инициации процессов развития в количественном и качественном измерении, что требует качественного пересмотра роли и значения персонала - от объекта маркетингового воздействия к субъекту маркетинговых отношений, способному как к масштабированию, так и к мультиплицированию бизнеса «материнской» компанию.

Авторская модель также позволяет уточнить и формализовать стратегическую матрицу И. Ансоффа «продукция - рынки - вектор географического роста», в рамках которой доступна реализация следующих направлений масштабирования / мультиплицирования:

- собственно географического развития;

- поиска и монетизации конкурентных преимуществ ресурсного и маркетингового типов;

- извлечения дополнительного экономического эффекта, связанного с синергическим эффектом (на втором и третьем этапах взаимодействия с персоналом материнская компания экономит на программах вовлеченности и лояльности персонала, минимизирует последствия неоправданной текучести и операционные издержки кадрового направления);

- стратегической гибкости (которая проявляется в опережении процессов масштабирования / мультиплицирования над процессами секвестрования малопроизводительных или бесперспективных видов и направлений экономической деятельности материнской компании). 
По сути, авторская разработка является логическим переходом от модели И. Ансоффа к конкретному стратегическому маркетинговому плану участив я в действующей конфигурации рынков сбыта либо создании новых, а также оптимизации ассортимента и территорий операционной активности.

Использование данной модели в практике маркетингового управления персоналом предприятия означает переход от тактического к стратегическому масштабу маркетинговой активности, подразумевающему партнерский тип взаимодействия на определенной ступени личного, командного профессионального и организационного развития.Для материнской компании дочерние и мультиплицированные структуры становятся потоком потребителей, для которых достаточно реализации ресурсной компетенции - конкурентоспособного доступа к общим и/или уникальным условиям и факторам экономической деятельности, остальные функции и компетенции, по сути, выносятся на аутсорсинг с соответствующей экономией ресурсов на реализацию управленческой деятельности, которые могут и должны быть перенаправлены в непрерывный процесс воспроизводства человеческого капитала - способного к самостоятельной деятельности и эффективному маркетинговому взаимодействую персонала исходной организации.

Подводя итог сказанному, отметим, что использование предлагаемой модели на практике подразумевает изменение формата кадровой политики и стратегии современных предприятий и организаций, переход к стратегическому маркетинговому взаимодействию со всеми категориями персонала на разных стадиях их профессионального жизненного цикла, расширение масштабов использования специфических маркетинговых инструментов взаимодействия с перспективными, потенциальными, действующими, «потерянными» работниками.

Реализация указанной модели выгодна не только «материнской» компании, становящейся по сути узлом предпринимательской инфраструктуры, но и самим работникам, обладающим реальной возможностью самореализации, а также всей системе субъектов и институтов рынка трудовых ресурсов (государство, профсоюзы, ассоциации работодателей, прочие субъекты), поскольку обладает значительным потенциалом гармонизации трудовых отношений на базе партнерской маркетинговой идеологии и их продуктивного развития, направленного на системный рост эффективности использования кадрового потенциала современных организаций.

$$
* * *
$$

1. Бондаренко В.А.Ключевая роль персональной компоненты в инфраструктурных и управленческих трансформациях // Менеджмент в России и за рубежом. 2006. № 6.

2. Воронов А.А.Конкуренция и конкурентоспособность: количественные методы оценки. Монография. Краснодар, КубГУ, 2002.

\section{Kapa M.A. \\ Инновационные процессы в аграрном секторе экономики}

Кубанский государственный аграрный университет имени И. Т. Трубилина

(Россия, Краснодар)

doi: $10.18411 / l j-28-02-2018-08$

idsp: 000001:lj-28-02-2018-08

\section{Аннотация}

В данной статье рассмотрены инновационные процессы в аграрном секторе экономики, их необходимость для России. Приводятся значительные нововведения в растениеводстве, животноводстве, в том числе развитие кролиководства, инициируемого КубГАУ. Также, выявлены проблемы и пути их решения.

Ключевые слова: инновации, агропромышленный комплекс, направления инноваций. 